\title{
Legal Liability for Euthanasia Actions in the Perspective of the Medical Code of Ethics in Indonesia
}

\author{
Hendra Wijaya ${ }^{1}$, NyomanSerikat Putra Jaya ${ }^{2}$, Bambang Joyo Supeno ${ }^{3}$, Aga Natalis ${ }^{4}$ \\ ${ }^{1}$ Doctoral Student University 17 Agustus 1945, Indonesia, ${ }^{2}$ Professors Diponegoro University, Indonesia, ${ }^{3}$ Associate \\ Professor University 17 Agustus 1945, Indonesia, ${ }^{4}$ Associate Professor Semarang University, Indonesia
}

\begin{abstract}
Introduction: Euthanasia which is done by doctors to their patients is considered as a part of the act of human rights violations, this matter would raise a dilemma for those who are pursuing a medical profession. Therefore, it is necessary to conduct research concerning legal liability related to euthanasia from the perspective of a medical code of ethics in Indonesia.

Purpose: This research aims to acknowledge and analyze the legal liability related to euthanasia from the perspective of a medical code of ethics in Indonesia.

Research Methodology: This research uses qualitative method with a normative juridical approach. The data collection technique is done through literature study.

Conclusion: Doctors must not neglect the obligation to always protect human life, as regulated in the medical code of ethics in Indonesia so that the act of euthanasia is contrary to professional and legal ethics and if it continues to be carried out, it can create criminal liability as regulated in the Criminal Code.
\end{abstract}

Keywords: Law; Euthanasia; Medical Code of Ethics.

\section{Introduction}

In Indonesia, the tools of regulating human rights have been regulated through the constitution and various laws and regulations under it as an implementing regulation. The 1945 Constitution of the Republic of Indonesia, both before and after the amendment, explicitly states that every citizen has freedom, not only freedom of association in expressing opinions in public, but also the freedom to live and embrace a religion, which is not only aimed to individualist protection but also collective. Likewise, access to freedom in the political and legal fields has been limitedly regulated through the provisions of Article 27 and Article 28 of the 1945 Constitution of the Republic of Indonesia. ${ }^{1}$

\section{Corresponding Authors:}

\section{Hendra Wijaya}

University 17 Agustus 1945, Pemuda Street, Semarang

City, Indonesia

e-mail: hendrawijaya4400@gmail.com
Regarding the freedom to determine self-fortune related to euthanasia, in various international regulations, it is emphasized through various international conventions which essentially do notrespond to the implementation of medical actions to end one's life based on their request or their family request through the medical actions performed by a doctor ${ }^{2}$. In the Universal Declaration of Human Rights in the provisions of Article 3 , it is stated that "Everyone has the right to life, liberty and the security of person". This provision indicates that the right to instruct ending someone's life is part of a violation of human rights ${ }^{3}$.

Legal liability concerning the implementation of the profession in medical procedures, including medical euthanasia, according to Anny Isfandyarie, is distinguished between the responsibility for professional provisions or medical code of ethics and the responsibility for legal provisions contained in the $\mathrm{law}^{4}$.

Based on the provisions of Article 344 of the Criminal Code, euthanasia is categorized as a crime 
against life. Euthanasia is legally a murder at the request of the victim, that is, the patient's request to the doctor ${ }^{5}$. Articles that can be applied to euthanasia are articles regarding murder, namely Articles 338, 340, 344, and 345 of the Criminal Code.

The experts of religion, morals, medicine, and law have not met the same agreement in facing euthanasia, especially at the person's request of death to end their suffering. This situation raises a dilemma for the doctors, whether they have the legal rights to end a patient's life based on their request or their family's request, with a reason to end the patient's long-term suffering, without the doctor faces legal consequences, which in this case, is a criminal threat as regulated in the Criminal Code. Of course, in this case, the doctor faced a conflict in their mind ${ }^{6}$. Therefore, it is important to research legal liability related to euthanasia in the medical code of ethics in Indonesia.

From the previous background, the purpose of this study is to acknowledge and analyze legal liability related to euthanasia from the perspective of a medical code of ethics in Indonesia.

\section{Research Methodology}

This study uses a qualitative research method with a normative juridical approach. The normative juridical research method is research on the principles of positive law written in statutory regulations and aims to conceptualize law as a written method. SoerjonoSoekanto argues that only legal research carried out by examining library materials or secondary data alone can be called normative legal research ${ }^{7}$. Data collection is carried out by a literature study to collect legal materials, such as laws, law books, and legal research journals related to the topic of this research.

\section{Discussion}

Euthanasia Study Group from Koninklijke Nederlandsche Maatschappij tot bevordering der Geneeskunst/KNMG (Dutch Medical Association) gives limitation for euthanasia, as follows: "Euthanasia deliberately does not do anything to prolong a patient's life or deliberately does something to shorten or end a patient's life, and all is done specifically for the patient's

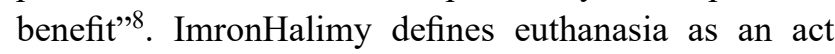
of stopping someone's life who is suffering from their illness, whether done sooner or later by a doctor or health team who treats them either at the request of the patient or the patient's family to reduce the burden of suffering. According to forensic medicine, euthanasia is a form of murder, where a person is killed to end someone's suffering, which is often found in cases of incurable cancer and the patient's closest people decide 9 .

Based on some of the definitions above, what is meant by euthanasia, in general, is taking action intending to shorten one's life or end one's life due to long-term suffering from an illness that cannot be cured by a doctor at the request concerned in these matters.

In general, euthanasia can be divided into two, which are as follows:

1. Active Euthanasia (mercy killing): Namely where a doctor or other medical personnel deliberately takes an action to shorten the patient's life or end the patient's life. It is considered as active euthanasia because the doctor took an action. Active euthanasia can occur because of request or not upon request ${ }^{10}$, the meaning is as follows:

a. Upon request (voluntary euthanasia): Active euthanasia on request is also called voluntary euthanasia because a patient voluntarily asks to end their life.

b. Without a request (involuntary euthanasia): Active euthanasia without request is also called forced euthanasia because the action is not done at the request of the patient.

2. Passive Euthanasia: Namely where doctors or other medical personnel deliberately stop providing medical assistance to patients that can support their life. So, it is not by taking any action that will directly result in the end of the patient's life ${ }^{11}$.

From all the analyzes above, juridically, Euthanasia, especially active euthanasia is indeed a criminal act, but not everyone who commits a criminal act should be punished. Barder Johan Nasution stated that the existence of a medical code of ethics aims to prioritize the interests and safety of patients, ensuring that the medical profession is always carried out with noble intentions and in the right way 9 .

Thus, society does not need to worry too much that euthanasia will very easily be carried out by a doctor, although of course doctors are also human beings who cannot possibly be free from mistakes and wrong considerations. Control is needed in addition to the right legal in terms of euthanasia ${ }^{12}$. 
Apart from the Indonesian Medical Code of Ethics and Article 344 of the Criminal Code, Indonesia has a legal instrument that regulates euthanasia ${ }^{13}$. This regulation only formulates actions seen from the point of view of protecting the patient without threatening a clear criminal rule. This regulation is Law Number 36 of 2009 concerning Health.

The formulation of articles that regulate euthanasia is contained in Article 56 of Law Number 36 of 2009 which regulates patient protection. The article states: Every person has the right to accept or reject part or all of the aid action that will be given to him or her after receiving and understanding the complete information regarding the action. The right to accept or reject as referred to in paragraph (1) does not apply to patients of a disease whose disease can quickly spread to the wider community; the condition of an unconscious person; or severe mental disorders. Provisions regarding the right to accept or reject as referred to in paragraph (1) shall be regulated following the provisions of statutory regulations.

From the formulation of Article 56 it can be understood that although the criminal act of passive euthanasia has not been regulated in Indonesian written law, the Health Law has explained that the right to receive or refuse treatment is invalid when the patient is unconscious. So that the act of passive euthanasia cannot be justified and can be threatened with a criminal penalty because the decision to accept or refuse treatment is entirely in the hands of the patient's family. Unlike the omission or pseudo euthanasia which cannot be punished if the patient is conscious and asks the doctor to stop all treatment for them.

The weakness from the formula in Article 344 of the Criminal Code is in the process of gaining the evidences, someone's request made intentionally and sincerely will be very difficult to be proved because the person who requested his life to be taken is already dead and cannot be asked for their testimony or witness.

Therefore, the sincere statement should not only be done orally, but also should be done in written form and signed by several witnesses, because, in the verification, the element of the sincere statement should be able to be proved by the witnesses or other evidences, as stated in Article 184 of the Code of Criminal Procedure, that is the testimony of a witness, the testimony of an expert, a document, an indication, and the testimony of the accused. However, the existence of proof of request cannot make the action acceptable. The action can still be reached by Article 344 of the Criminal Code.

Another weakness from the formulation of Euthanasia action in Indonesia is there is no explanation that the perpetrator of the criminal action is a doctor and the victim is the patient because the element from Article 344 of the Criminal Code is only stated by "Whoever". Therefore, the interpretation of the Article will be wider because the element is not stated clearly.

Generally, there are two kinds of ethics: general ethics and professional ethics. For the general ethics, someone who wants their family member to be quickly dead is considered unacceptable, but if the patient is having a very serious illness, for instance, having a severe illness for a long time where the condition of the body is emaciated, only bones wrapped in skin and the cancer wounds continue to expand and emit a very strong odor over a considerable distance, the people around will feel sorry for the patient and will not blame the patient's family too much if the family "would prefer it if the patient died soon".

The other kind of ethics is professional ethics. In this case, a doctor's professional ethics, or a medical worker's are pledged to the oath stated when they are initiated to be a doctor. The current doctor's oath pronunciation is following the Decree of the Minister of Health No. 434/MENKES/SK/X/1983 dated October 28,1983 , which essentially contains a code of ethics for the medical profession and this serves as a guideline for doctor's behavior in carrying out their profession.

The Indonesian Medical Code of Ethics regarding the obligations of doctors to sufferers in Article 11 states that every doctor must always remember his obligation to protect human life. From this ethical point of view, Euthanasia is against Indonesian medical ethics. This statement is true it is not only contradicting the medical ethics in Indonesia but also to the Hippocratic Oath which is the basis of the oath of doctors around the world. In medical ethics that is rooted in the Hippocratic Oath, it is stated that doctors will respect every human life from conception. This means that after a meeting between the egg or ovum and the sperm, the presence of the fertilized egg must be respected ${ }^{14}$.

Regarding life, the doctor's oath states that a doctor will respect life from the moment of conception. Thus, as long as there is life, that life must be respected. Even 
if life is not of a healthy quality, which in this case is very painful and makes people around them feel pity for them, it still has to be respected. However, the way to respect it depends on the views held by the people around or the doctor. Some read the Yaasin, some asked what holds them so that it should be removed immediately, some gave incantations or medicines, and of course, some suggested or by the patient asked for Euthanasia. One of the most common and most confusing moral dilemmas in health care arises when moral principles concerning whether health care workers should improve the patient's condition or respect the patient's autonomy clashes. Doctors and other healthcare professionals are obliged to do what is beneficial to the patients and not only preventing harm to them.

The reason Euthanasia until now is considered terrible, inhuman, violating the right to life, and so on, is because it is seen from an ethical perspective, both general ethics and professional ethics. Understanding medical ethics is a demand that is seen as increasingly necessary, serious handling of medical ethics issues is quite urgent. Medical ethics discusses doctors' ethics in carrying out their profession ${ }^{15}$. Medical ethics is very noteworthy in this profession. Starting from when they were students, prospective doctors have been given bioethics course material, even not only ethics towards fellow humans or patients, but also ethics in dealing with or manipulating experimental animals and corpses used for lessons. Ethics towards fellow humans is not only ethics towards patients but also teaches how to behave towards peers, teachers, and others.

Many people easily give moral judgments on others based on that person's outward behavior. To judge so is self-guilty. We never know how the intent and conviction of the person when they are doing something the good and the bad depends on whether he acts accordingly or not according to his consciences. The same thing also applies to a doctor's actions, even though they have been bound by the doctor's oath and their behavior can be seen, what they perceive cannot be seen from the outside.

Guwandi in his book called it a trilogy of medical secrets, which consists of informed consent, medical records, and medical secrecy. The regulation of medical secret matters is stated in the context of Medical Ethics and Law. Ethics and medical secrets are stated in the Hippocratic Oath which is always spoken by doctors who just graduated from their education. The original
Hippocratic Oath was composed by a small group of Pythagorean medical from the island of Coss in the late fourth century $\mathrm{BC}^{16}$.

The Hippocratic Oath provides instructions regarding medical ethics, namely: that it fulfills the need for an instruction and coordinated registration from a doctor. The public should be protected wherever possible from con artists who are not doctors. The doctor takes action for the benefit of the patients. Doctors must do everything in their power to provide treatment. They must not do something that they know will harm their patients. Euthanasia and abortion are prohibited. Lithotomy guidelines may also forbid performing mutilating operations such as castration. There is also a limitation that only those skilled in the art are allowed to do so. An outline of the nature of the doctorpatient relationship is provided. For example, to take advantage of this relationship is not justified. Finally, the Hippocratic Oath confirms the doctrine of Medical Secrets.

Hippocrates of Greece, Galenus, and Rome are some of the pioneers of ancient medicine who had laid the foundation for the establishment of a noble medical tradition. Together with all medical figures and organizations in international forums, they then intend to base these traditions and medical disciplines on a professional ethic. This ethic, all the time prioritizes patients who seek treatment and for the safety and interests of the sufferers. This ethic itself contains principles, namely: beneficence, non-maleficence, autonomy, and justice ${ }^{17}$.

With this principle, the doctor who treats his patient must consider that his action must be useful for his patient or the principle of beneficence, if it is not useful, at least it must not harm the patient or the principle of non-maleficence which has the right of autonomy over his own body. The last, a doctor must be fair or aligned with the principle of justice.

The code of ethics stated by Mustika, as quoted by SuryaniSoepardan, is the norm that must be paid attention to by every profession in carrying out their professional duties and their lives in society. These norms contain instructions for members of the profession on how they should carry out their profession and their prohibitions, namely provisions regarding what members of the profession can and cannot do, not only in carrying out their professional duties but also regarding general behavior in daily interactions. 
According to SigitLesmonojati, today's demands call for medical practice to prioritize ethical principles. The modern ethical principles are such that is taken from Catherine Tay Swee Kian: the principle of Autonomy, the principle of Generosity, the principle of Not Hurting, the principle of Justice, the principle of Loyalty, and the principle of Honesty ${ }^{18}$.

The Indonesian Medical Code of Ethics states that a doctor has general obligations, such $\mathbf{a s}^{19}$ :

1. Every doctor must uphold, live, and practice the doctor's oath.

2. Must always strive to carry out his profession according to the highest professional standards.

3. Must not be influenced by something that results in the loss of freedom and professional independence.

4. Avoid having vanity.

5. Any action or advice that may be psychologically or physically debilitating is only given for the benefit and benefit of the patient, after obtaining consent.

6. Be wary of announcing discoveries.

7. Only provide certificates and opinions that have been self-checked for the truth.

8. Provide competent medical care, technical and moral freedom, with compassion and respect for human dignity.

9. Honest in dealing with patients and colleagues, remind colleagues if there are deficiencies, fraud, and embezzlement in handling patients.

10. Respect the rights of patients, the rights of colleagues, the rights of other health workers, and must keep the patient's trust.

11. Always remember the obligation to protect human life.

12. Paying attention to the interests of the public and paying attention to all aspects of comprehensive health services, whether physical, psychosocial and trying to be true educators and community servants.

13. In cooperation with health officials and others must respect each other.

\section{Obligations to Patients:}

1. Have a sincere attitude, use all knowledge and skills for the benefit of the patient. If unable, with the patient's consent, refer to others who are capable.
2. Allow the patient to connect with his family and counselors in terms of religious acts and/or other problems.

3. Must keep everything they know about a patient to themselves, even after the patient has died.

4. Obliged to carry out emergency aid as a humanitarian task, unless there is someone else who is certainly willing and able.

\section{Obligations to peers:}

1. Treat peers as they would like to be treated.

2. Must not take over the patient from a peer, except with consent or based on ethical procedures.

\section{Towards oneself:}

1. Must keep being healthy, so that one can work properly.

2. Keep informed of the developments in medical/ health science and technology.

Therefore, it is clear that the Indonesian Medical Code of Ethics prohibits active and passive euthanasia. In other words, doctors cannot act as a God (don't play God). Medical ethics must be pro-life, not pro-death. A doctor is a person who saves or enhances life, not a person who determines life itself (lifesavers, not life judgers). There is no need for further explanation on how the matter of Euthanasia for the parties involved is problematic that cannot simply be solved and overcome. The implementation of Euthanasia action to terminal patients is simply an act that flows from a deep source of humanity and out of respect for the wants of others. The doctor's emotional involvement is the only reason why he is willing to offer real help to a patient who is dying.

Thus ethically, it is not allowed for doctors to kill a dying patient. If a doctor is proven to practice Euthanasia of the patient because of pity for seeing his pain, then he has violated the Decree of the Indonesian Medical Council number 17/KKI/KEP/VIII/2006 concerning Guidelines for the Enforcement of Medical Discipline, which states that 'every doctor is not allowed to commit an act that is aimed at ending human life, because it is not only contradicting to the Medical Oath and/or medical ethics and or the objectives of the medical profession but also it is against the rules of criminal law.'

Because ethical norms do not cover strict penalties for doctors who continue to engage in Euthanasia to their patients, they must be returned to what is regulated 
by the Criminal Code regarding this matter. Article 344 of the Criminal Code states that "Whoever takes the life of another person at the request of his person, which he calls real and sincere, is sentenced to a maximum imprisonment of 12 years". Meanwhile, Article 345 of the Criminal Code states that 'Whoever induces another person to commit suicide, helps him in that act, or provides the means for him to do so is punishable by a maximum imprisonment of 4 years if that person commits suicide'.

\section{Conclusion}

The legal liability for euthanasia actions in the perspective of the medical code of ethics in Indonesia is that doctors must respect every human life from the moment of conception. In this case, it means that no matter how serious a patient's illness is, every doctor must still protect and defend the patient's life. In such circumstances, this patient may have been dying for months. However, in this relationship, the doctor must not escape from the obligation to always protect human life, as stated in his oath. Therefore, Euthanasia has no medical indication to achieve a concrete goal, except only to stop suffering from pain. Thus Euthanasia is contrary to professional and legal ethics and if it continues to be carried out, it can create criminal liability as regulated in the Criminal Code.

Ethical Clearance: Yes.

\section{Conflict of Interest: No}

Source of Funding: Authors

\section{References}

1. Hadiprayitno II. Defensive enforcement: Human rights in Indonesia. Hum Rights Rev. 2010;11(3):373-399. doi:10.1007/s12142-0090143-1

2. Banović B, Turanjanin V. Euthanasia: Murder or not: A comparative approach. Iran J Public Health. 2014;43(10):1316-1323.

3. McDonald LA. Human Trafficking as a Threat to the Security of Americans. 2018.

4. Hartanto NJ, Agustina A, Permana K. Criminal Violations of the Medical Ethics Code by Dr. Bimanesh. Fiat Justitia. 2018;12(4):329.

5. Tanuwijaya F. Euthanasia and the Assessment of Patients' Autonomy Rights in the Indonesian Criminal Code. Lentera Huk. 2020;7(2):231-244.
6. Sutarno. Euthanasia from the Perspective of Indonesian Norms. Syst Rev Pharm. 2020; 11(1):192-202.

7. Sari N. Consumer Protection of Drug in Indonesian Law: Examining The Paternalism Theory. Adv Soc Sci Educ Humanit Res. 2019;317(IConProCS):177-182.

8. Dierckx de Casterlé B, Verpoort C, De Bal N, Gastmans C. Nurses' views on their involvement in euthanasia: A Qualitative Study in Flanders (Belgium). J Med Ethics. 2006;32(4):187-192. doi:10.1136/jme.2005.011783

9. Halim A. Euthanasia In A Moral and Legal Perspective. Al-Mazahib. 2012;1(1):1-12.

10. Abohaimed S, Matar B, Al-Shimali H, et al. Attitudes of Physicians Towards Different Types of Euthanasia in Kuwait. Med Princ Pract. 2019;28(3):199-207.

11. Bishop JP. Euthanasia Efficiency and the Historical Distinction Between Killing a Patient and Allowing a Patient to Die. J Med Ethics. 2006;32(4):220-224.

12. Pereira J. Legalizing Euthanasia or Assisted Suicide: The Illusion of Safeguards and Controls. Curr Oncol. 2011;18(2):38-45.

13. Sofyan A. Euthanasia: Concept and Rule of Law in Indonesia. J Law, Policy Glob. 2017;58(0):27-32.

14. Merino S, Aruanno ME, Gelpi RJ, Rancich AM. The Prohibition of Euthanasia and Medical Oaths of Hippocratic Stemma. Acta Bioeth. 2017;23(1):171178.

15. Lagay F. Physician-Assisted Euicide: The Law and Professional Ethics. Virtual Mentor. 2003;5(1):1922.

16. Yustina EW. The Right to Public Information and the Right to Medical Secrets: Human Rights Problems in Health Services. Padjadjaran J Ilmu Huk. 2014;1(2):248-269.

17. Hajar R. The Air of History Early Medicine to Galen (Part I). Hear Views. 2012;13(3):120-128.

18. Lesmonojati S. Criminal Responsibility for Problem of Medical Action in Hospital. Surabaya: Scopindo Media Pustaka; 2020.

19. Murdi PB, Supanto, Novianto WT. The Role of Indonesian Honorary Council of Medical Discipline in Upholding Indonesian Medical Code of Ethics. Adv Soc Sci Educ Humanit Res. 2019;358(Icglow):111-114. 